\section{TWO NEW LOCALITIES OF SRI LANKAN RELICT ANT ANEURETUS SIMONI EMERY, 1893 (FORMICIDAE: ANEURETINAE) WITH THE VERY FIRST RECORD IN THE INTERMEDIATE ZONE}

\author{
D.A.G.N.B. Karunarathna ${ }^{1}$ \& W.A.I.P. Karunaratne ${ }^{2}$ \\ ${ }^{1,2}$ Department of Zoology, Faculty of Science, University of Peradeniya, \\ Peradeniya 20400, Sri Lanka \\ ${ }^{1}$ nuwan_bk@yahoo.com, ${ }^{2}$ inokap@pdn.ac.lk (corresponding author)
}

Aneuretus is the only living genus of the tribe Aneuretini (Formicidae: Aneuretinae), with all other genera (Aneuretellus, Protaneuretus, Paraneuretus and Mianeuretus) being extinct (Bolton 1994). The only extant Aneuretus species is $A$. simoni (Sri Lankan Relict Ant) (Image 1), an endemic to Sri Lanka (Wilson et al. 1956; Jayasuriya \& Traniello 1985) that is classified as Critically Endangered by the IUCN, mainly due to its limited distribution (Social Insects Specialist group 1996). Earlier, the phylogenetic position of $A$. simoni was thought to be intermediate between primitive and advanced subfamilies of ants (Wilson et al. 1956), but recent studies have shown that it is the nearest living relative of subfamily Dolichoderinae (Brady et al. 2006; Ward et al. 2010). Thus $A$. simoni has played a major role in understanding the evolution of Dolichoderinae (Ward et al. 2010).

Aneuretus simoni was first described (Emery 1893) based on a collection made in 1892 from Kandy. However, until 1955 it was known only from a few specimens in museum collections worldwide. In 1955, adult and larval morphology of $A$. simoni together with its distribution and ecology were studied by a group of scientists who visited Sri Lanka (Wilson et al. 1956). According to Wilson et al. (1956), A. simoni was distributed in five localities, namely Ratnapura, Gilimale, Adam's Peak, Peradeniya and Kandy in the wet zone of Sri Lanka (Fig. 1). Later, in

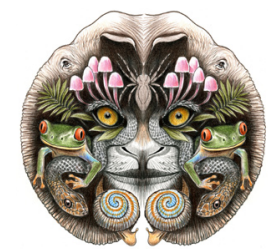

ISSN

Online 0974-7907 Print 0974-7893

\section{OPEN ACCESS} 1979, Jayasuriya \& Traniello (1985) conducted a survey in Sri Lanka to study the distribution, abundance and foraging behavior of $A$. simoni. After surveying several localities, including locations from which this ant was previously recorded, $A$. simoni was collected only from Gilimale Forest Reserve (a lowland rain forest; average elevation $152 \mathrm{~m}$ ) in the Ratnapura District.

Recent investigations have resulted in the discovery of $A$. simoni from Pompekelle, a secondary forest in the Ratnapura District (Chaminda \& Dias 2001; Dias 2004) and again from Gilimale in 2004 (Dias 2008). This species was also recorded from Sinharaja Forest Reserve (a lowland rain forest extending into Ratnapura, Kalutara and Matara districts), in 2005 by Perera et al. (2006) and during the period from 2005-2007 by Gunawardene et al. (2008). In 2009 A. simoni was discovered from 'Kirikanda', a lowland rain forest habitat in the Kalutara District located very close to the Sinharaja boundary (Dias et al. 2011) (Fig. 1).

Up until this current study $A$. simoni was recorded only from forests of the island's wet zone, where mean annual rainfall is $>2,500 \mathrm{~mm}$. Hence the persistence of lowland rain forest conditions (higher rainfall and low elevations) of the wet zone of Sri Lanka has permitted the continued survival of this species. However, during

DOI: http://dx.doi.org/10.11609/JoTT.03334.4604-7 | ZooBank: urn:Isid:zoobank.org:pub:5FFAB328-7102-46FA-9F31-E1CF2AB9A848
$\begin{array}{ll}\text { Editor: Brian Fisher, California Academy of Sciences, USA. } & \text { Date of publication: } 26 \text { July } 2013 \text { (online \& print) }\end{array}$

Manuscript details: Ms \# 03334 | Received 04 September 2012 | Final received 07 June 2013 | Finally accepted 22 June 2013

Citation: Karunarathna, D.A.G.N.B. \& W.A.I.P. Karunaratne (2013). Two new localities of Sri Lankan Relict Ant Aneuretus simoni Emery, 1893 (Formicidae: Aneuretinae) with the very first record in the intermediate zone. Journal of Threatened Taxa 5(11): 4604-4607; http://dx.doi.org/10.11609/JoTT.o3334.4604-7

Copyright: ( ) Karunarathna \& Karunaratne 2013. Creative Commons Attribution 3.0 Unported License. JoTT allows unrestricted use of this article in any medium, reproduction and distribution by providing adequate credit to the authors and the source of publication.

Funding: This study was self-funded by authors.

Competing Interest: None.

Acknowledgements: Authors thank Forest Department of Sri Lanka (permit no. R\&E/RES/NFSRC/11) and Department of Wildlife Conservation (permit no. $\mathrm{WL} / 3 / 2 / 1 / 7$ ) for permitting access and specimens collection from the Knuckles Forest Reserve; to Divisional Secretary, Panwila for granting permission to work in Moraella forest (permit no. PV/A/5/3/01/II). We are grateful to Prof. J.P. Edirisinghe for accommodating us with their field visits. We thank Mr. M.P. Ranaweera for guiding us in Moraella forest, and Mr. N. Wijayathilaka for photographing specimens. Dr. A.S.T.B. Wijetunga is acknowledged for his clarification on the vegetation types of the selected habitats. Field assistance given by P.G.N.J. Bandara, G.W.B. Ellepola, G.C.P. Diyes and Y. Edirisinghe is highly acknowledged. 


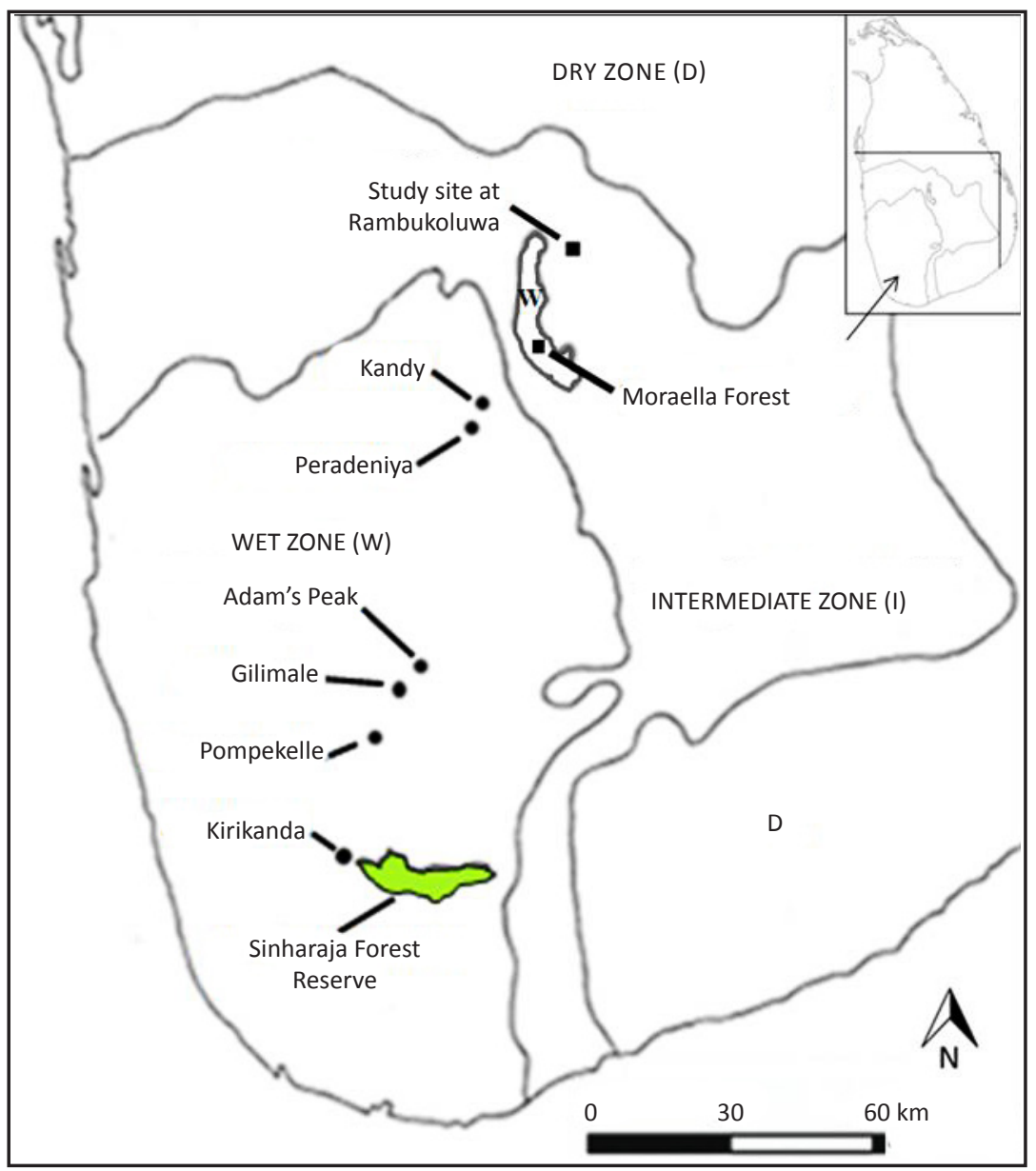

Figure 1. Map of Sri Lanka showing the localities from where Aneuretus simoni has been collected up to date (modified from Wilson et al. 1956).

an ongoing study of ants in the central part of Sri Lanka, this rare ant was discovered from two new localities, extending its range within the wet zone and into the intermediate zone of the island.

Materials and Methods: Field work was conducted from October 2011 to March 2012 to investigate the species composition of litter ant fauna in the Knuckles Mountain Range, which spans mainly the intermediate zone of Sri Lanka (Bambaradeniya \& Ekanayake 2003). Two sites were surveyed for ants, the lowland rainforest in Moraella, in the wet zone and the semi-evergreen forest of Rambukoluwa in the intermediate zone (Fig. 1). Moraella forest $\left(7^{0} 21^{\prime} 50.67^{\prime \prime} N\right.$ \& $\left.80^{\circ} 44^{\prime} 5.91^{\prime \prime} E\right)$ is a recently discovered fragmented wet lowland rain forest at 500-700 m elevation in the valley of Kukul Oya (oya=stream) in the southwestern foothills of Knuckles Range. Of the 204 plant species discovered in Moraella forest, 89 are endemic to Sri Lanka while 39 are nationally threatened (Medawatte et al. 2011). The vegetation is mainly comprised of trees of the family
Dipterocarpaceae such as Dipterocarpus zeylanicus, Shorea dyeri and Vateria copallifera (Medawatte et al. 2011). The forest is situated in the Panwila Division in Kandy District within an area receiving a mean annual rainfall of 2500-3000 mm (National Atlas 1988).

The second field site was located in a well established forest in Rambukoluwa (7032'54.56"N \& 8047'28.79"E) below $700 \mathrm{~m}$ elevation in the Matale District. The major natural vegetation type in the lower elevation of the Knuckles Mountain Range is semi-evergreen forests that harbour many large trees that shed their leaves during the long dry and windy season from July to August. The forest consists of three strata: canopy (20-25 m), sub-canopy (15-10 m) and scanty ground herbaceous vegetation (Bambaradeniya \& Ekanayake 2003). Mean annual rainfall of the area is $>2000 \mathrm{~mm}$ (National Atlas 2007).

Three $100 \mathrm{~m}$ transects were laid out in each forest type and the ants were collected in twelve $1 \times 1 \mathrm{~m}$ quadrats along each transect using two established methods: 

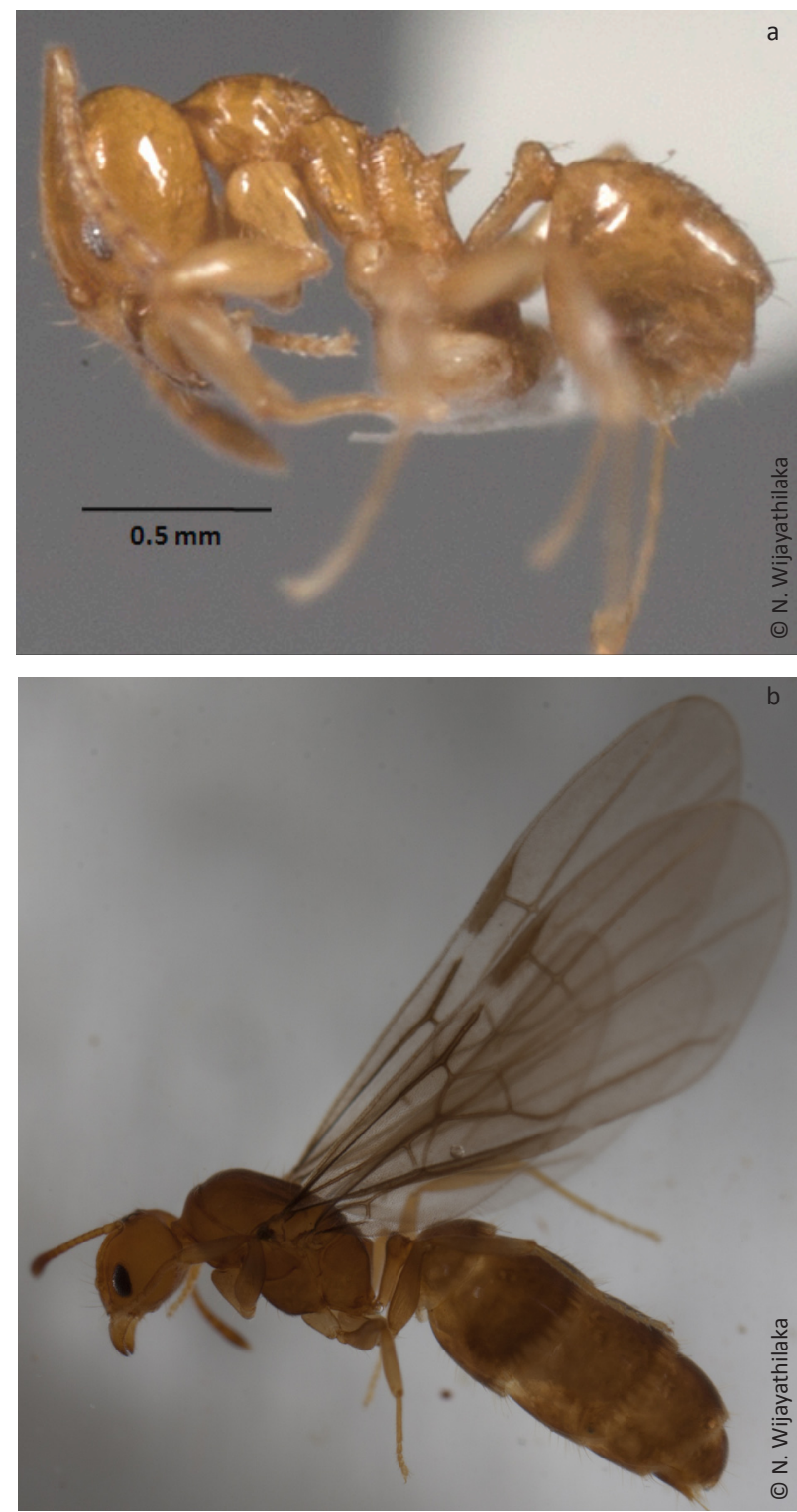

Image 1. Profile view of a worker (a) and a queen (b) of Aneuretus simoni.

Winkler extraction and hand collection. In six quadrats ants were hand collected for three hours by two people, while in the other six ants were extracted using the MiniWinkler method (Bestelmeyer et al. 2000). Additionally, ants were collected randomly outside the transect using forceps. Collected ants were preserved in $70 \%$ alcohol and voucher specimens were deposited in Invertebrate Systematics and Diversity Facility at Department of Zoology, University of Peradeniya.

Results and Discussion: A total of 155 Aneuretus simoni workers were collected from four quadrats along one transect (average elevation 592m) in the Moraella forest (relative abundance 1\%) and from three quadrats along two transects (average elevation $549 \mathrm{~m}$ ) in the semi evergreen forest (relative abundance $2.6 \%$ ). Relative abundance of $A$. simoni along the transect laid in the Moraella forest and in the two transects laid in the semi evergreen forest were $6 \%, 3.8 \%$ and $2.5 \%$ respectively. From all the transects, hand collection yielded only 13 A. simoni workers, and the rest of the individuals (92\%) were collected using Winkler extraction method.

Random collections made in semi-evergreen forest revealed that $A$. simoni is an inhabitant of forest edges. Despite its rarity, this is unsurprising as Wilson et al. (1956) have reported this ant as being abundantly present at forest edges, even at edges of clearings. This collection in semi-evergreen forest supports the fact that A. simoni is adapted to forest clearings and it does not require deep rain forest conditions for survival (Wilson et al. 1956). However, rainfall seems to be an important factor for the distribution of this species. Mean annual rainfall of the two new localities is $>2,000 \mathrm{~mm}$ supporting the previous findings that the rainfall range of 2,000$5,000 \mathrm{~mm}$ favours distribution of $A$. simoni (Jayasuriya \& Traniello 1985). The fact that $A$. simoni has been recorded from Udawattakele Sanctuary in Kandy, a noticeably drier forest than forests in Ratnapura area (Wilson et al. 1956), and its discovery from semi-evergreen forests, which experience a long dry spell and desiccating winds during July-August, may suggest that $A$. simoni has some adaptations to drier conditions as well, and hence can be expected from drier habitats. Studies carried out in Kahalla-Pallekele forest, Dambulla and Anuradhapura sanctuary in the dry zone of Sri Lanka, however, have not recorded this species so far (Dias \& Peiris 2008; Dias \& Kosgamage 2008). Jayasuriya \& Traniello (1985) further stated that elevations above $450 \mathrm{~m}$, which is the case in two new localities (592m and $549 \mathrm{~m}$ ), are correlated with the distribution of $A$. simoni. However, this ant has been recorded from much lower elevations such as $112 \mathrm{~m}$ in Kirikanda forest (Dias et al. 2011).

The discovery of $A$. simoni from semi-evergreen forests at Rambukoluwa area extends its distribution to Matale District and is the first record of this species from the intermediate zone of the country. In addition, this study emphasizes the importance of Knuckles Mountain Range as an area with important biodiversity. Although $A$. simoni had been reported from Kandy District in the early days (Emery 1893; Wilson et al. 1956) its presence was not re-confirmed in later studies (Jayasuriya \& Traniello 1985) until the present study in Moraella forest in the Kandy District. Findings of the present study highlight the importance of recording the current distribution of $A$. simoni within the country to re-evaluate the 
conservation status of this world's sole representative ant species of the subfamily Aneuretinae.

\section{REFERENCES}

Bambaradeniya, C.N.B. \& S.P. Ekanayake (2003). A Guide to the Biodiversity of Knuckles Forest Region. The World Conservation Union, Sri Lanka, vi+68pp.

Bestelmeyer, B.T., D. Agosti, L.E. Alonso, C.R.F. Brandao, W.L. Brown Jr., J.H.C. Delabie \& R. Silvester (2000). Field techniques for the study of ground-dwelling ants, pp 122-144. In: Agosti D., J.D. Majer, L.E. Alonso \& T.R. Schultz (eds.). Ants: Standard Methods for Measuring and Monitoring Biodiversity. Smithsonian Institute Press, Washington, DC, xix+280pp.

Bolton, B. (1994). Identification Guide to the Ant Genera of the World. Harvard University Press, USA, 222pp.

Brady, S.G., T.R. Schultz, B.L. Fisher \& P.S. Ward (2006). Evaluating alternative hypotheses for the early evolution and diversification of ants. Proceedings of the National Academy of Science 103(48): 18172-18177; http://dx.doi.org/10.1073/pnas.0605858103

Chaminda, K.M.G.R. \& R.K.S. Dias (2001). Taxonomic key for the identification of Sri Lankan ants: subfamilies. Abstract booklet of the Third ANeT Seminar and Workshop held in Hanoi, Vietnam, 11.

Dias, R.K.S. (2004). Taxonomic key for the subfamilies of ants recorded from Sri Lanka and some information on Aneuretus simoni Emery in "Pompekelle," Ratnapura. Spolia Ceylanica 41: 92-101.

Dias, R.K.S. (2008). Amazing ants - present status of research on ants of Sri Lanka, pp. 1-9. In: Kumarasinghe, N.C. (ed.). Social Insects and their Economic Importance and Conservation. SLAAS and Biodiversity Secretariat of the Ministry of Environment and Natural Resources, Sri Lanka, 28pp.

Dias, R.K.S. \& K.R.K.A Kosgamage (2008). Systematics and community composition of foraging worker ants (Family: Formicidae) collected from three habitats in a dry zone region of Sri Lanka. Proceedings of the Annual Research Symposium, Faculty of Graduate Studies, University of Kelaniya, 115pp.

Dias, R.K.S. \& H.A.W.S. Peiris (2008). Similarities and differences of the ant communities recorded from three types of habitat in Anuradhapura region. Proceedings of the Annual Research Symposoim, Faculty of Graduate Studies, University of Kelaniya, 113-114pp.

Dias, R.K.S., H.A.W.S. Peiris \& H.P.G.R.C. Ruchirani (2011). Discovery of Aneuretus simoni Emery in a disturbed forest in Kalutara, and Stereomyrmex horni Emery in Anuradhapura Sanctuary, Sri Lanka. Asian Myrmecology 4: 99-102.

Emery, C. (1893). Voyage de M.E. Simon á l'île de Ceylan (janvierfévrier 1892). Formicides. Annales de la Société Entomologique de France 62: 239-258.

Gunawardene, N.R., J.D. Majer \& J.P. Edirisinghe (2008). Diversity and richness of ant species in a lowland wet forest reserve in Sri Lanka. Asian Myrmecology 2: 71-83.

Jayasuriya, A.K. \& J.F.A. Traniello(1985). The biology of the primitive ant Aneuretus simoni (Emery) (Formicidae: Aneuretinae) I - Distribution, abundance, colony structure and foraging ecology. Insectes Sociaux 32(4): 363-374; http://dx.doi.org/10.1007/BF02224014

Medawatte, W.W.M.A.B., E.M.B. Ekanayake, K.U. Tennakoon, C.V.S. Gunatilleke \& I.A.U.N. Gunatilleke (2011). A floristic survey of a unique lowland rain forest in Moraella in the Knuckles Valley, Sri Lanka. Ceylon Journal of Science (Biological Sciences) 40(1): 33-51; http://dx.doi.org/10.4038/cjsbs.v40i1.3405

National Atlas of Sri Lanka (1988). The National Atlas of Sri Lanka. Survey Department Sri Lanka, 142pp.

National Atlas of Sri Lanka (2007). The National Atlas of Sri Lanka. Survey Department Sri Lanka, 243pp.

Perera, K.A.M., R.K.S. Dias \& S. Yamane (2006). The first record of Aneuretus simoni Emery (Sri Lankan Relict Ant) from Sinharaja Forest and its relative abundance estimated by several sampling methods. Proceedings of the Sri Lanka Association for the Advancement of Science 413/D: 74-75.

Social Insects Specialist Group (1996). Aneuretus simoni. In: IUCN 2013. IUCN Red List of Threatened Species. Version 2013.1. <www. iucnredlist.org>. Downloaded on 15 July 2013.

Ward, P.S., S.G. Brady, B.L. Fisher \& T.R. Schultz (2010). Phylogeny and biogeography of dolichoderine ants: effects of data partitioning and relict taxa on historical inference. Systematic Biology 59(3): 342362; http://dx.doi.org/10.1093/sysbio/syq012

Wilson, E.O., T. Eisner, G.C. Wheeler \& J. Wheeler (1956). Aneuretus simoni Emery, a major link in ant evolution. Bulletin of the Museum of Comparative Zoology (Harvard) 115: 81-99. 